\title{
Cultivating Decline: Agricultural Modernization Policy and Adaptive Resilience in the Yangzi Delta
}

\author{
Ross Doll ${ }^{1}$ \\ Accepted: 6 December 2020 / Published online: 4 February 2021 \\ (C) The Author(s) 2021
}

\begin{abstract}
Since it was initiated in the mid-2000s, the Chinese central government's agricultural modernization policy has had fundamental impacts on China's agricultural system. Premised on creating a foundation for long-term sustainable development, modernization has broadly expanded large-scale, mechanized farming. Historically, however, China's Yangzi River Delta achieved long-term sustainable development without capital-intensifying and mechanizing technological innovation. Rather, diverse and autonomous land use and grassroots governance practices facilitated knowledge-sharing, knowledge-building, and adaptation. Drawing on this history as a reference point for analysis, I examine the influence of agricultural modernization policy on adaptive resilience using a case study of a Yangzi Delta township that was an early recipient of central government funding in support of its contemporary effort to expand large-scale farming. I find that the implementation of agricultural modernization policy reform in Ruilin has undermined its resilient practices and features, rendering the township vulnerable to disturbance.
\end{abstract}

Keywords Resilience $\cdot$ Agriculture $\cdot$ Development $\cdot$ Modernization $\cdot$ Agrarian change $\cdot$ Yangzi Delta $\cdot$ China

\section{Introduction}

Beginning in the mid-2000s, the Chinese central government began funding the expansion of domestic large-scale production of grain and other agricultural commodities. Government support for that goal has grown in intervening years, with the state investing US $\$ 500$ billion between 2013 and 2020 alone (China Daily 2013, 2016). The state's efforts have brought about rapid changes to China's countryside: from 2008 to 2014 the percentage of arable land transferred ${ }^{1}$ increased from $8.6 \%$ to $28.8 \%$, while the percentage of mechanically sown arable land increased from about $42 \%$ to $62 \%$ (Li et al. 2017; Wang et al. 2016).

The state has argued that this reform is necessary given the shift of workers and investment capital from China's

\footnotetext{
${ }^{1}$ Chinese state legislation designates all rural land the property of village collectives, who grant member households usufructuary rights on 30-year contracts. While members cannot sell this land, they may transfer, subcontract, lease, or exchange their contracted usufructuary rights. Thus, land transfer rates provide insight into the rural land market (National People's Congress 1999, 2002).
}

Ross Doll

rossdoll@berkeley.edu

1 Department of Geography, University of California at Berkeley, 505 McCone Hall \#4740, Berkeley, CA 94720-4740, USA countryside to its cities. State leaders assert that by turning the work of food production over to subsidized and labor efficient large-scale farmers, agricultural modernization will offer the countryside and nation a basis for long-term sustainable development (see Wen 2006).

Historically however, China's states and rural societies achieved long-term sustainable development via alternative practices aligned with resilient agroecology. In the Yangzi River Delta region, farmers and leaders maintained agricultural surpluses from approximately $1000 \mathrm{AD}$ to the 1950 s without capital-intensifying or mechanizing technological innovation. This occurred despite population levels increasing by perhaps $700 \%$ (Ellis and Wang 1997). Yangzi Delta farming regions were typically autonomous and diverse at the levels of species, horizontal and vertical spatiality, marketing, governance, and community relations. These characteristics in turn facilitated sharing, learning, adaption, and knowledge-building. The state played a critical role, ensuring the sustainability of this development both by investing in water control and extension, protecting peasants from exploitation, and by adapting its policies based on communication across governance and spatial scales. Together, these hallmarks, features, and practices allowed the Yangzi Delta system to anticipate, buffer, and respond to change and disturbances.

Drawing on this history as a reference point for analysis (Table 1; see Whiting et al. 2019), I examine the influence of 


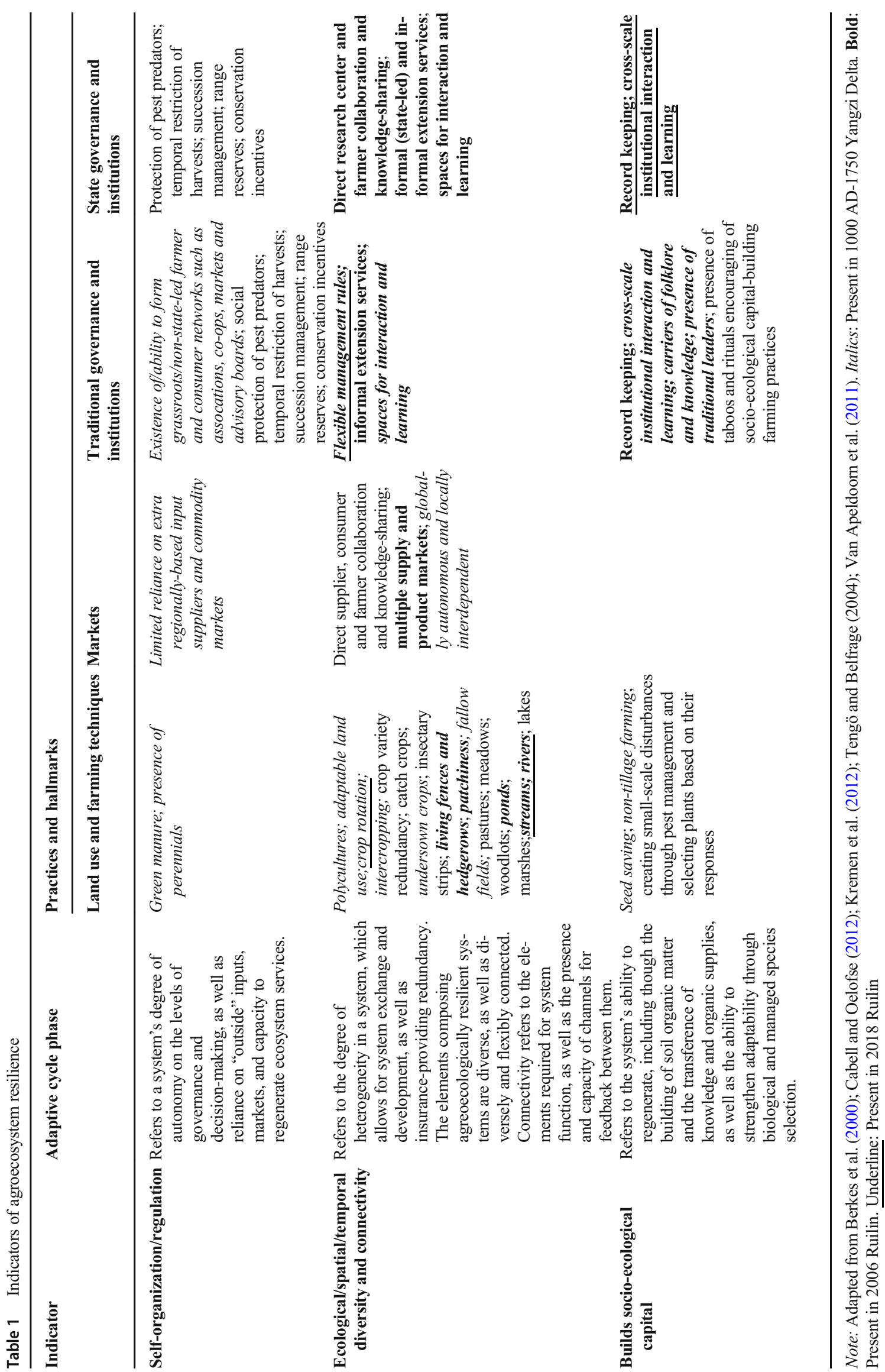


agricultural modernization policy on adaptive resilience, or the capacity to buffer disturbances and maintain productivity. I use as a case study "Ruilin," a township in the Yangzi Delta province of Anhui that was among the earliest recipients of central government funding in support of large-scale farming. Between receiving its first funding award in 2007 and its completion of modernization work in 2018 Ruilin was transformed: $99 \%$ of its arable land was consolidated, of which $61 \%$ was transferred to 135 large-scale enterprises.

I conducted a total of 12 months of ethnographic fieldwork in Ruilin over three years $(2014,2017$, and 2018). Fieldwork consisted of participant observation and 220 formal and informal interviews with small-scale farmers, large-scale farmers, township and county officials, and retailers and producers involved in agricultural marketing, processing, and supply. Based on this research, I find that the implementation of agricultural modernization policy reform in Ruilin has undermined its adaptive resilience practices, conditions, and features. The creation of consolidated, contiguous plots for large-scale and mechanized farming has reduced landscape patchiness and land cover diversity. Government standards and support for large-scale farming enterprises have consolidated land in the hands of elites and outsiders with little or no local farming experience, marginalizing Ruilin's grassroots leaders. While the new large-scale farms are more labor-efficient than smallscale farms, their large sizes and often complex management structures render them less productive on a per-hectare basis, as well as less responsive to natural disasters. The new large-scale farms are more reliant on industrially produced chemical and mechanical inputs. Finally, modernization has directed the attention of Ruilin government leaders away from the interests of its majority small-farmer population, which in turn reduces its and the state's - knowledge of on-the-ground conditions. While these changes may have long-term implications, in the short term they have already increased Ruilin farms' vulnerability to natural disasters and land waste, as well as decreased their per-hectare productivity.

\section{Theorizing Resilience Ecology}

Researchers of agricultural societies have found in Gunderson and Holling's (2002) theories salient means of conceptualizing the reasons why farming systems persist or decline. These theories have informed principles of agroecology, understood here as the application of ecological principles to agricultural systems and practices. Adaptive farming systems able to buffer disturbances and continue producing are protected by higher level governments from disturbances, which monitor and restrict potential sources of vulnerability, such as markets for lending, inputs, and land. At the same time, in adaptive systems states have limited authority. Farmers possess a high

\footnotetext{
${ }^{2}$ All names of places in Anhui Province and personal names are pseudonyms.
}

degree of autonomy, including in governance and marketing. Finally, adaptive systems are diverse vertically (intercropping), horizontally ("patchy" landscapes), as well as in marketing, oversight, and community relations. These characteristics expand the potential for novel interactions, experimentation, and sensitivity to environmental change. These systems also retain that knowledge, including through recordkeeping, seed-saving, and soil regeneration (Table 1; Berkes et al. 2000; Cabell and Oelofse 2012; Kremen et al. 2012; Tengö and Belfrage 2004; Van Apeldoorn et al. 2011). Ultimately, these factors self-reinforce: an understanding of place-based vulnerabilities encourages diverse connections as contingencies for disturbance, and vice-versa.

Gunderson and Holling emphasize that maladaptive systems of all kinds can also achieve high levels of resilience. ${ }^{3}$ Wealthy, tightly regulated systems where potential is high and connectedness is great may be able to apply these resources, capital, and political command to resist external disturbances and internal variance. But the resilience capacity of such systems masks their vulnerability. Having consolidated power, system components have little incentive to engage outside of small homogeneous networks. They become complacent, settling into uncoordinated, predictable routines. Communication, learning, and adaptation slow (see Sen 1989). As a result, such systems may fail to anticipate disturbances, and may lack the creative capacity to adequately respond to disturbances, leading to "rigidity traps." They may also interpret disturbances not as warnings of structural failings, but as threats to existing power structures, and respond by imposing more centralized order. Rigid systems having grown unaware of spatial diversity and given little incentive to consider alternatives to governing orthodoxy - are prone to creating environmental management policies misaligned with diverse conditions or competing interests (Cumming et al. 2006). For these reasons, "all such systems are likely to have the seeds of their own destruction built in" (Holling 2001: 400401).

\section{The Rise and Fall of Resilient Agroecology in the Historic Yangzi Delta}

Practices and hallmarks of resilience agroecology were critical to the ability of Yangzi Delta farmers to sustain productivity for over 1000 years. State leaders drew on the peasantry as a tax base, and rural society was in general highly stratified. As a result of its dependence on peasant agriculture and rural

\footnotetext{
${ }^{3}$ Critics have noted key shortcomings of Gunderson and Holling's resilience conceptual framework. Given that seemingly "outside" elements, such as those associated with colonization and globalization, can trigger rapid and fundamental change, what defines the borders of a system, and how can systems "adapt" as though possessing cohesiveness or will? Others have noted that system change is often unpredictable and fails to conform to cyclical patterns (Gotts 2007). Acknowledging such shortcomings, Gunderson and Holling emphasize the metaphorical rather than literal nature of the resilience conceptual framework.
} 
society more broadly, however, the state also protected it and worked to enhance its productivity. Empires during this time invested heavily to promote Yangzi Delta agriculture as well as famine prevention, in particular the Song (960-1279) and Qing (1644-1912) states. Qing measures focused on constructing and maintaining county ever-normal granaries (changpingcang). The state ensured their supply by reviewing required detailed monthly agricultural reports from county magistrates (Davis 2000; Li 1982). In addition, states in this era introduced inputs such as new seed varieties and promoted water control and production through building and maintaining canals, dykes, and irrigation systems (Bray 1986; Shih 1992).

In addition to these preventative measures, state leaders intervened to protect peasant societies and agricultural production from natural disasters and exploitative rural elites. Floods and droughts commonly occurred during the Ming and Qing eras. In response, the state re-supplied granaries via a subsidized grain tribute system, which it maintained by state-supported transport networks (Davis 2000; Li 1982). The state also funded the reconstruction of public works (He 2015, Tian 2015). When wealthy Delta families took advantage of a rural leadership vacuum in the fifteenth century to appropriate control over irrigation systems, Ming dynasty (1368-1644) leaders deployed the military to restore peasant access (Huang 1990). Qing emperors used monthly reports and ever-normal granaries to monitor and suppress grain speculation. This level of scrutiny encouraged accuracy in reporting and led to reforms (Davis 2000). Such state interventions provided stability and a foundation for prosperity not just for the Yangzi Delta region but the whole country.

At the same time, state leaders afforded Yangzi Delta communities high degrees of autonomy in day to day governance. During the Song Dynasty, the work of maintaining and improving grain production and adjudicating disputes fell to powerful county-level tax captains (Shih 1992). They were replaced in the Ming Dynasty by landlords. Rural elites often played a key role in preventing and responding to natural disasters by funding the maintenance of canals and dykes in the fields immediately adjacent to them, as well as by donating food and supplies (Huang 1990; Tian 2015). In the aftermath of the fifteenth century peasant tax revolts and the subsequent flight of the landlords to the cities, peasant lineage and solidarity groups assumed local governance roles. These groups managed water control and established charity lands that dramatically reduced peasant landlessness (Shih 1992). Peasant lineage and solidarity groups were also at the forefront of short-term disaster relief. Their proximity and knowledge allowed them to efficiently and effectively coordinate emergency response with the state and elites (Tian 2015). In general, over this long dynastic period rural Delta society "was independent of state initiative in maintaining a favorable condition for agricultural production" (Shih 1992: 179).
These levels of governance protection, connection, and autonomy shaped, and were shaped by, Delta peasant farming practices and market exchanges. Delta villagers commonly cultivated polycultures, engaged in double cropping and intercropping, and supplemented animal and human wastebased fertilizers with compost and canal sludge. These methods worked to control pests, regenerate soil, and safeguard against crop diseases. Scattered and patchy plots, networks of canals and ditches, ponds, dykes, living mulberry plant fences and wasteland all contributed to vertical and horizontal landscape heterogeneity that built knowledge and soil capital (Bray 1986; Ellis and Wang 1997). As late as the 1930s peasants predominantly produced and consumed household goods and farm inputs on-site (Ellis and Wang 1997; Huang 1990; Skinner 1995). Exceptions were bought or sold in what William Skinner refers to as standard market towns, typically located no more than three miles from any village (Eastman 1988). By providing peasants with a means of hedging against short-term shortages and exchanging information with diverse actors, these markets increased resilience.

The success of the Qing state's policies set in motion a compounding series of unintended consequences. State antifamine measures encouraged migration and fertility throughout the country (Will et al. 1991). Supplemented by the state's grain policies and encouraged by a growing market for cotton, peasants began devoting increasing amounts of their land to cash-cropping. Quality of life improvements drove both increased fertility and rents, which in turn encouraged greater investment in cotton production. Peripheral regions grew dependent on the state's grain transport network and thus vulnerable to breakdowns within it. When the Opium Wars (1839-1842, 1856-1860) drained Qing state finances and reduced its ability to restore granaries, normally manageable incidents of flood and drought took devastating tolls on livelihoods and mortality. These incidents in turn sparked insurrections, in particular the Dungan Revolt (1862-1877) and the Taiping Rebellion (1850-1864) (Davis 2000). The Yangzi Delta's ties to market-based inter-regional trade networks, easy access to water transport, and proximity to treaty ports helped to insulate it from the growing national crisis. By the 1850 s, however, the Qing state was no longer capable of defending the region. Taiping armies overran farming communities in places like Ruilin, to horrific effect (Platt 2012). Due largely to the Taiping Rebellion, the Delta experienced its first catastrophic drop in population in centuries (Huang 1990).

Yangzi Delta populations rebounded in the aftermath of the Taiping Rebellion, but, in an effort to stave off collapse, the state imposed higher taxes on landlords, who in turn raised peasant rents (Bernhardt 1992). To satisfy these demands as well as maintain and improve their quality of life, peasants once again increasingly turned to cotton. As before, this fed a cycle of "involution," as peasants devoted increasing 
amounts of labor and capital to farming for diminishing returns (Elvin 2004; Huang 1990). As taxes and peasant revolts sapped landlord power and peasant households exhausted their land and themselves, the Delta system became newly vulnerable to revolutionary upheaval.

\section{CCP Agricultural Policy Reforms and their Influence in Ruilin, 1949-2006}

In this context of 200 years of instability and declining livelihood security, broadly associated with and attributed to expanding Western imperialism, the Chinese Communist Party (CCP) assumed power and sought to restore autonomy both expediently and free of Western influence. The state adopted a Soviet-style command economy to quickly build industrial capacity via channeling agricultural surpluses to support industry. To maximize its extraction of peasant grain, the state organized peasants into collectives, fixed the enormous rural labor force in place via a repressive household registration (hukou) system, and instituted a compulsory grain procurement (Chan and Wei 2019). To support the command economy, it relied on a vast bureaucracy, adapted the imperial-era administrative hierarchy to organize spatial units and disburse resources, and established a quantitative evaluation system to manage officials (Chan 2010; Whiting 2001).

Early policies, however, relied on both intensive top-down ideology and bureaucratic rationality, with disastrous results. In resilience terms, the state applied its extraordinary well of potential to impose a highly connected, inflexible system. This was most dramatically expressed by the Great Leap Forward (1958-61), a nation-level mass labor mobilization effort to improve agricultural productivity unveiled in the context of Mao's campaign to root out political critics. Unwilling to question or report on the effects of unsuitable state policies, officials and farmers continued to carry out central orders (Harrell in this issue). Approximately 20-40 million people died from starvation (Becker 1996; Dikötter 2010; Smil 1999; Yang 2007). Agricultural Anhui Province, upriver from the central Delta industrial centers, was severely impacted, with birth rates dropping to $42 \%$ of their projected trend (Garnaut 2014).

In the wake of the Great Leap Forward campaign, decisionmaking power was once again decentralized. Production teams, or village groups - in Ruilin typically composed of 10-30 households - became the most basic level of administration. In place of mass labor mobilization, the state began promoting Green Revolution-style technology and mechanization: improved seed varieties, the tractor plow, monocropping, and chemical inputs. Nationally, the use of chemical fertilizers increased more than threefold between 1970 and 1981 (Muldavin 2000; Tong et al. 2003). The use of chemical fertilizers further increased in the 1980s and 1990s, as decollectivization, the proliferation of household farming, and market logics encouraged short-term approaches to land and resource use (Jiang 2003; Patton 2015). In Ruilin, the expanded use of chemical fertilizers in the 1990s led farmers to reduce the practice of growing a soil-regenerating third season. The state's efforts to ensure equitable household landholdings required periodic land readjustments, which in turn resulted in the inefficient dispersal of households' landholdings. By the late 1990s, Ruilin households' contracted landholdings averaged six $m u^{4}$ (.4 ha), but that land was commonly scattered across $7-10$ plots throughout the village - conditions that reduced labor efficiency.

But CCP reforms also helped to sustain many adaptive resilient practices in some form. Much as corvee labor did in the imperial era, collectivization provided the state with virtually cost-free labor that it used to install elaborate irrigation and drainage canals and dykes, build rural infrastructure, and introduce electrified pumping (Bray 1986; Huang 1990; Muldavin 2000; Stavis 1974). In Ruilin, collectivization led to immediate improvements in water management. Beginning in the mid-1950s, the rural government organized Ruilin villagers to build a levee along the Kui River to the east of the township, along with a series of water pumping stations. The Shan River, which bisects the town from north to south, was also created and connected to the Kui, along with a dam south of Ruilin town. Between the Kui and the Shan villagers built elaborate irrigation and drainage canals. All of these helped to substantially decrease incidents of flooding and drought that historically had troubled the township on near-annual basis. In the 1950s, Ruilin farmers began broadly double-cropping rice as well as a third season of safflower, purple sage, or rape to regenerate the soil.

Decentralized governance after the Great Leap gave production teams the autonomy to decide critical matters, including members' water use. Collectivization encouraged cooperation. Households pooled labor to maintain or improve public goods. They also pooled money to purchase shared inputs, such as tractors and electric pumping stations, reforms that produced the bumper harvests of the early and mid-1980s (Huang 1990; Muldavin 2000). Finally, in restoring collectives as a basic administration unit, the state also removed restrictions on household garden plots that rural people used for subsistence and cash-cropping (Huang 1990).

Given the importance of grain production to the command economic model, the state supported an extensive agricultural technology extension service system. In addition, the "FourClass Agricultural Science Network" of 1974 created agricultural science stations at every rural governance level. Together, these often experimental services introduced farmers to new products, techniques, and information, provided guidance and training, and facilitated discussion (Yun 2006; Zhang 2005). The state adjusted the agricultural

\footnotetext{
$\overline{{ }^{4} 1 m u=.067 \text { ha }}$.
} 
technology service system for dispersed households by establishing both village-level technicians and science and technology demonstration households. In addition, beginning in the 1980s the township agricultural technology station organized annual multi-day trainings for technicians and demonstration households responsible for conveying what they learned to other village households.

Unlike many parts of the country, Ruilin's relative remoteness limited its ability to develop rural enterprises. Beginning in the 1980s, a small number of residents began migrating to urban centers for temporary labor, primarily as factory workers, waiters, and care workers in Nanjing, Hangzhou, Shanghai, and the municipal capital. The number of migrant workers increased substantially in the 1990s along with the rise of the urban-based export economy and widening urbanrural economic gaps. By 2007, 6873 of Ruilin's 30,000 people labored full-time outside the township (Yangchun County 2003). With the increase in migrant workers, a practice of spontaneous land leasing began. Migrant households established informal arrangements with friends and neighbors to caretake their land and pay agricultural taxes - and sometimes a nominal rent - in exchange for the permission to cultivate it. These farmers were typically $50-70$ years of age, too old for the urban labor market. They accumulated landholdings based on economies of scale, typically between 15 and $30 m u$ (1-2 ha), the upper limit was restricted in part by the difficulty of irrigating, planting, harvesting, and tilling dispersed plots (He 2011; Sun 2017). The rural sociologist He Xuefeng refers to these farmers as "middle farmers" (zhongnong). By combining their farming incomes with part-time laboring, middle farmer households could earn salaries commensurate with those of their neighbors laboring in the cities. Due in part to their investments in their land, middle farmers often took leadership roles, acting as production team leaders, advocating for the rights of their communities, and maintaining customs and traditions (He 2011).

While the small overall holdings of Ruilin farmers limited their profitability, they also offered significant advantages. Based on local conditions, Ruilin farmers typically had only a two-week window in July between the time when they could harvest their early rice and needed to complete the transplanting of their late rice. Ruilin's intense summer heat only increased the work's difficulty. Midday July temperatures in Ruilin typically reach $40{ }^{\circ} \mathrm{C}$, necessitating that farmers concentrate their work in morning (4 am-10 am) and evening (5 pm-10 pm). Small scales of landholding rendered such productivity possible. Further, small scales reduced rural people's vulnerability. According to Ruilin's agritech station head, when his office historically issued warnings of impending pest, disease, or extreme weather-related threats, farmers often had only $1-$ 2 days to respond. Such immediate response times are also necessary in the wake of disasters. The relatively small sizes of small- and mid-scale farmer holdings allow them to adapt quickly, thoroughly, and carefully. Limited landholdings allowed small-scale farmers to retain familiarity with the conditions of their fields, which in turn allowed them to quickly notice and respond to such problems. As a result, the station chief reports that prior to 2007, crop losses in Ruilin were typically minor and limited. Finally, when assessed on a per-hectare unit basis farmers' small plots were conducive to productive rice farming, which requires even water levels to avoid waterlogged or dried plants.

As they had been historically, irrigation ponds remained critical to Ruilin rice farming. Each of Ruilin's 13 administrative villages contained an average of 100 such ponds that farmers accessed using motorized pumps. In interviews, Ruilin small-scale farmers often equated the condition of irrigation ponds - their depth, size, and the quality of their water - with that of the land and its harvests. So critical was the perceived link between irrigation ponds and the surrounding land that in interviews small-scale farmers often did not consider them separable. For this reason, small-scale farmers established informal but strictly enforced pond use rights. Small-scale farmers also used their land for subsistence farming, growing vegetables, and raising poultry, livestock, and fish. These practices allowed them to reduce their expenses and sustain themselves during years of poor harvests.

\section{Agricultural Modernization Policy Reform}

\section{Background}

In contrast to the relative calm in Ruilin at the time, by the late 1990s much of China's countryside was seething. The state had implemented a series of significant liberalizing reforms in the 1980s. The decentralization of property rights that ushered in decollectivization and household farming was accompanied by fiscal decentralization and reforms to officials' evaluation criteria that prioritized GDP growth (Whiting 2001). Central state funding for public goods and agricultural extension evaporated (Yan 2008). Rural officials were now responsible for funding their own budgets as well as policy mandates passed down from administratively higher-level government (Tsui and Wang 2004). At the same time, the state retained foundational Mao-era structures. The household administrative system continued to tie individuals' social security benefits to the administrative area of their birth, a policy with the effect of creating a migrant labor underclass (Chan 2010). Villagers continued to have few secure formal means of influencing rural governments, including reliable channels to communicate grievances to higher-level leaders (O'Brien and Li 2006). 
As foreign direct and state investment flooded China's cities following the state's market reforms, another vicious cycle emerged. Increasingly desperate rural officials shifted their focus away from the interests of their farming constituents to industrial growth (Kung et al. 2013). Unchecked by the governance system, many officials became predatory, imposing excessive agricultural taxes and fees and exploiting legal loopholes to expropriate land to sell to developers for windfall profits (Tsui 2011). Sizeable livelihood gaps began to emerge between rural and urban populations, evident in economic-, health-, and education-related indicators - gaps feeding and exacerbated by the flight of rural people to the booming cities in search of work. These conditions boiled over in conflicts between rural people and officials, which increased in both number and visibility (Hanstad et al. 2009). In resilience terms, the system had once again accumulated extraordinary potential at the cost of diversity and autonomy.

In response, the state undertook reforms aimed at rejuvenating the countryside. Reversing its historical practice of extracting from the countryside, the state eliminated agricultural taxes and fees and introduced subsidies to encourage industry investment. Key among the state's policy goals was agricultural modernization. As a policy goal and practice, agricultural modernization was not new. The Chinese government articulated the goal of instituting a modernized agricultural production system, understood at the time as mechanized and large-scale collective, during its first National People's Congress in 1954 (Thomas 1956). The state made this intention more explicit in 1964, when Premier Zhou Enlai included agricultural modernization as one of the "Four Modernizations" (Ye 2015). The concept resurfaced in the 1990s in response to growing criticism among some central officials of the household farming-based system (Zhang and Donaldson 2008). By that time, however, agricultural modernization had come to denote the kind of large-scale, mechanized, capitalized, and vertically integrated farms common in the industrialized West. Beginning in the 1990s the state began pursuing initiatives intended to promote capitalized agriculture by linking China's small family farms' pre- and postproduction purchasing, processing, and marketing activities with industry and consumers (Gürel 2014; Schneider 2017). Modernized agriculture - in the form of chemical inputs - also expanded after decollectivization as a result of both extension agent referrals and farmers' market-influenced decisions.

But where previous policies attempted to maximize the productive capacity of small-scale farms, the agricultural modernization policies initiated in the mid-2000s proposed the more radical goal of replacing small-scale farmers with large-scale producers. In 2005, the central government for the first time proposed the idea of broadly cultivating new business entities as a part of developing modern agriculture. In turn, the central ministries of Land and Resources and Finance earmarked funds for construction projects in the areas of land consolidation: land remediation and the demolition of rural housing to create new urban land ("increase-decrease linked projects"); reconstruction of low and medium-yield fields; and high standard farmland demonstration.

\section{Agricultural Modernization Reform in Ruilin}

Around 2006 the then-deputy head of agriculture in Ruilin's governing county of Yangchun, noting the central government's embrace of large-scale farming, applied to the Anhui provincial Land and Resources Bureau for land consolidation project funding. Yangchun county's bid, focused on the Ruilin villages of Lin, Wang, and Mei, proposed to build irrigation facilities, roads, and to redesign fields to facilitate large-scale farming. The county and township governments coordinated with the provincial design institute on blueprints. In the view of the county deputy head, the bigger the farming scale, the more likely to please administratively superior officials. To this end, plans called for increasing the size of plots to between 10 and $50 m u$ (.66-3.3 ha). The county's bid also included land transfer ratio targets on township officials' evaluations, which are linked with promotions and funding. Based on practices in neighboring townships as well as the financial needs of both the new state-subsidized large-scale farmers and small-scale farmers, the county and township settled on a standard annual rental rate of $400 \mathrm{jin}(200 \mathrm{~kg})$ of rice per $m u{ }^{6}$

The county and township government sought out a Ruilin businessman named Zheng Feiyu to act as the county's first large-scale farmer. At the time, Zheng owned the largest grain processing and input retail business in Ruilin. Officials requested that Zheng contract $2000 \mathrm{mu}$ (133.3 ha) on a nineyear basis. Given his lack of large-scale farming experience, Zheng was reluctant. To encourage him, officials both threatened punishments and offered enticements, including offering to pay one-quarter of his land rent as well as promising future rewards and compensation. In addition, Zheng could collect subsidies as a certified leading enterprise. After agreeing the contract, Zheng immediately sub-contracted almost all his land to friends and relatives, most of whom were from outside the township, and with whom he established exclusive supply and marketing agreements. Yet because these agreements were informal, the township could continue to claim that Zheng operated a large-scale, modern farm.

\footnotetext{
${ }^{5}$ In order to protect the nation's supply of arable land from development, in 2007 the Chinese central government instituted a strict "red line" policy requiring governments to maintain a specified minimum supply of arable land under their authority. This policy allowed government officials to convert arable land to non-agricultural land use designations so long as they offset the lost amount through the establishment of more arable land within their administrative areas (Day and Schneider 2018).

${ }^{6}$ In 2013 the Chinese state's minimum purchasing price for late indica rice was RMB 1.25 per jin (RMB 2.5/kg). In 2018, the minimum price was 1.5 per jin (RMB 3/kg). Thus, 400 jin of late indica rice was worth approximately RMB 500 in 2013, and RMB 600 in 2018 (China Daily 2012, China Daily 2017).
} 
The township tasked village committees with carrying out negotiations with Lin, Wang, and Mei villagers. Villagers greeted the officials' plans with enthusiasm. Approximately $20 \%$ - most of whom were already leasing their land to a middle farmer - were happy to transfer their land to dahu ("large households," but denoting state-subsidized large-scale farmers) in exchange for substantially higher rent. Most of the remainder supported the plan to consolidate their farmland, thus easing their farming labor. Construction began in the middle of 2007. In order to compensate for a harvest of late rice lost due to construction, most farmers left to labor outside Ruilin. Upon their return during the 2008 Lunar New Year, they discovered that nearly all their irrigation ponds had been filled in and removed. The township retained only a handful to allow for laundry and firefighting. As a result, the only way for most farmers to access water was through a pump connected to a new irrigation canal. Intended for large-scale production, these pumps irrigate hundreds and even thousands of $m u$ per day, or the equivalent of a production team or administrative village. Thus, the use of such pumps requires a high degree of villager coordination. Further, access to them requires permission from township officials. In addition, villagers' newly consolidated land was uneven. Observing these conditions, many villagers abandoned their plans and signed their land over to dahu, primarily Zheng Feiyu. Those who protested faced intense pressure and coercion from village officials. Ultimately, over $90 \%$ of farmers in Lin, Wang, and Mei villages transferred their land, almost $7000 \mathrm{mu}$ (466 ha), to dahu.

The Yangchun county government redoubled its commitment to large-scale farming after the central government formally expressed its support in its 2008 Third Plenary Session. All farmers contracting over $100 \mathrm{mu}$ (6.6 ha) through the government were eligible to receive $80 \mathrm{yuan} / \mathrm{mu}$ in government subsidies, up to 100,000 yuan in low-interest loans from the county rural credit union, and the subsidized coverage of $50 \%$ of their insurance. These subsidies attracted considerable interest from investors, and only one-third of all bids were awarded land. The township government formally tasked village committees with selecting $d a h u$, with villagers and then Ruilin locals given priority. But the county and township governments also made it known that they prioritized bids of over $1000 \mathrm{mu}$ (66.6 ha) and required 500 yuan/mu security deposits. The initial capital requirements of contracting at these scales - over RMB 1 million including security deposit and rent ${ }^{7}$ - excluded the vast majority of Ruilin residents. Ultimately, all five successful bidders contracted over $1000 \mathrm{mu}$, with one exception who contracted $925 \mathrm{mu}$ (61.6 ha).

\footnotetext{
$\overline{7}$ Based on 2013 Chinese state minimum late rice purchasing prices. By 2018, contracting $1000 \mathrm{mu}$ of land in Ruilin required RMB 1.1 million (see Footnote $3)$.
}

These "mega dahu" of state subsidized farmers contracting over $1000 \mathrm{mu}$ experienced significant operational and financial struggles. Most initially attempted to follow the practice of small-scale farmers and used their land to double-crop rice. Harvesting and transplanting at such production scales within the two-week July window requires substantial labor. Yet the transfer process reduced the pool of potential laborers, as many of the dispossessed had left the township to pursue work in the cities. Other potential laborers were engaged in their own harvesting and planting. As a result, mega dahu initially had little choice other than to leave substantial portions of their fields unplanted. In 2009, small-scale farmers' output of late rice averaged $1000 \mathrm{~kg} / \mathrm{mu}$, while dahu harvested averaged only $500 \mathrm{~kg} / \mathrm{mu}$, and some produced no yields at all. Dahu responded by changing their planting pattern to the double-cropping of medium rice and winter wheat. Unlike late rice, medium rice has the advantage of not requiring transplanting, thus significantly reducing labor needs. But based on data compiled through fieldwork interviews, dahu rice production remained $200-400 \mathrm{~kg}$ lower than average per $m u$ small-scale farmers' medium rice outputs.

Farm management issues are key to the problem. Even with reduced labor needs, mega dahu still require dozens of laborers to work hundreds of $m u$, rendering constant supervision impossible. Given low wages and little accountability, laborers have little incentive to work hard. Instead, they take shortcuts, such as pulling weeds and leaving roots behind and dumping heavy buckets of fertilizer. With little ability to supervise their landholdings, dahu farmers are unable to quickly respond to natural disasters. As Sun (2017) points out, this is consistently reflected in insurance data. A 2014 fungus outbreak affected $51.4 \%$ of dahu land, but only $35.9 \%$ of Ruilin small-scale household-farmed land. Similarly, severe weather in 2013 caused lodging (the weakening and collapse of stems) across $69.4 \%$ of dahu early rice land, but only $35.7 \%$ of small-scale farmer land (ibid.: 185). Finally, large-scale plots are typically less evenly graded than small-scale plots, and thus more susceptible to waterlogging and drying. As a result, mega dahu have averaged annual losses of 128 yuan per $m u$. In response, other mega dahu began following Zheng Feiyu's example and subleasing their land.

Rates of small- to large-scale farmer land leasing declined in many villages after the initial push of 2007-2008. Key to this decline was small-scale farmer response. Small-scale farmers in most villages protested the potential loss of their ponds and, in the case of villages targeted for increasedecrease linked projects, their homes by registering collective complaints at village, township, and county offices and physically blocking bulldozers. When these efforts failed, some used hammers to break into irrigation canals or graded the unlevel land allocated to them by hand. A few villages were 
highly successful using these methods, with all or almost all of those willing to continue farming ultimately retaining their contracted land. I spoke with one villager who engaged in a successful collective protest:

The government must consider the common people. If you eliminate ponds, where will we get water? They are only concerned with elimination. They don't care if you live or die. Actually, the government plans it this way because they don't think about the possibility of us farming. All of the land is given to the dahu. When they reformed the land, we held a small group meeting to discuss the division of the land. In the meeting, the village cadres encouraged us all to stop farming and give the land to the $d a h u$. They said we would be happier laboring outside. But some can go out to labor, and some cannot. Laboring is not as good as farming your own land.

But in most cases where, as in the initial stage, the project was of particular political or economic significance to the rural government, officials met small-scale farmer resistance with overwhelming pressure. These efforts included threats to eliminate the businesses of holdouts' families, destroy their property and homes, and deny them access to government services such as the state's minimum government subsistence allowance (dibao). One holdout villager was approached by an official in public: "You don't give the government face!" the official told him. "If you need something from us, you should die, and you will die!"

Many gave up their resistance in the face of these conditions. Fifty-eight year old Zhang's land was targeted for land consolidation in 2012. He leased his land after a construction company filled in his irrigation ponds:

After the land was demolished, returning to farm again was really not easy. For many there was nothing else to do but give the land to the dahu. From the government's perspective, whether or not [the $d a h u$ ] make money or manage the land well, whether or not the people that have been hired [to manage reconstruction] are responsible, these sorts of things are not important.

I spoke with a villager who initially resisted the pressure village officials gave him to lease:

But after they filled in the ponds I gave up. I could have fought. I could have continued. But it wasn't worth it. Things had changed. I knew I couldn't succeed in farming.
In response to mega dahu production problems and the central government's promotion of smaller scale "family farms" in 2014, the rural government began prioritizing contracting at scales between 100 and $400 \mathrm{mu}$ (6.6-26.6 ha), and restricted incoming dahu to landholdings of $600 \mathrm{mu}$ (40 ha). Farming smaller scales has allowed family farms to largely overcome the mega dahu land and labor supervision problems, and family farms' middle rice production averages $25 \%$ more than that of mega dahu. Despite this, $100 \mathrm{mu}$ (6.6 ha) landholdings remain too large to accommodate early and late rice double-cropping. As a result, family farms, like mega dahu, also double crop medium rice and winter wheat. But winter wheat has proven unsuitable for Ruilin's wet and humid climate. Every year from 2014 to 2018 Ruilin dahu experienced extensive wheat crop losses due to fungus. According to the head of Ruilin's agritech station, over 90\% of Ruilin dahu either lost money or broke even during those years. Of the $40 d a h u$ with whom I spoke in 2017-2018, 25 stated that they were either not planning to renew their land contracts or were strongly considering doing so. Eight stated that they were either reducing their scale of wheat farming or forgoing it altogether. The Ruilin agritech station chief estimated that dahu farmers were leaving 15\% of the township's arable land fallow for at least half of the year. Xu Fei of Ding Village began contracting $100 \mathrm{mu}$ in 2014:

My wife and I used to hire laborers, but we can no longer afford it. We do everything ourselves now. We work all day, every day, but it barely makes a difference. We can't change the climate, we can't raise rice prices, and we can't lower rents. We can't succeed. It's as if the government never considered how we could succeed long term... I certainly regret contracting land.

The state's 2006 elimination of agricultural taxes and fees reshaped rural governance. The state eliminated the primary source of rural government finance, replacing it with competitive development project funds, including those intended to promote large scale farming. Yet on average these funds filled only a fraction of the new finance gap. In turn, village, township, and county government budgets and staffs were reduced and redirected towards procuring project funds, enticing investment, and developing business links. In addition, the state centralized control over rural government budgets and staffing (Fock and Wong 2008; Zhao 2007). This led to considerable changes to the state's extension service system. In Ruilin, the township government reduced the full-time staff of its agritech station office from an average of five to one. Ruilin village governments retained agricultural technicians, but also tasked them with other full-time jobs. Overworked village technicians ceased networking with households and simply posted new information on village government office bulletin boards. 
The expansion of large-scale farming under agricultural modernization exacerbated these effects. What remained of Ruilin's government-provided extension services was entirely redirected to dahu. Township training courses shifted their focus to cater to dahu management interests and needs. The township assigned demonstration households status to dahu alone. The work of village government agricultural technicians was transferred to dahu. In practice, however, that work was rarely done. One dahu recruited by his village government to train those in his production team told me:

In fact, I have never trained my neighbors. The village pays me a few hundred yuan a year for this work. I have $600 \mathrm{mu}$ to farm, a job, a family. I feel guilty for not doing this recruiting work, but how can it be my priority?

In the place of linking with households, the understaffed township extension office sends information to Ruilin farmers on official QQ, WeChat, and SMS accounts - platforms that tend to exclude Ruilin's predominantly poor, elderly, and illiterate small-scale farmer population. As a Ruilin villager put it, "[Small-scale farmers] don't have any rural services. Everything is for the dahu."

Input retailers have filled the void created by the departure of the state from extension work. The township agritech station provides information on pests and diseases to retailers, and most small-scale farmers report that they rely on input retailers for information on new products, varieties, and techniques. Yet according to the township agritech chief, many retailers abuse their position, disregarding government advice in favor of recommending small-scale farmers apply excessive quantities of the most expensive products. In the absence of effective guidance, Ruilin small-scale farmers commonly overuse pesticides and fertilizers. For example, the county government suggests that area farmers apply pesticides to their middle and late rice 4-5 times per season. Yet half of all Ruilin small-scale farmers apply twice that amount. This in turn not only unnecessarily increases small-scale farmers' costs, but also leaves poisonous residues on rice and increases pest resistance, which in turn requires greater pesticide use. The Yangchun county director of the Plant Protection Station explained:

There is an indicator problem in disease and insect treatment and control. We only release disease and insect information when the number of diseases and insects reaches a certain index. Otherwise, there is no need to apply pesticides. Using pesticides when you see crop damage from a pest will only increase pests' resistance. But agricultural retailers do not consider this issue. They let farmers apply pesticide in order to sell pesticide. The short-term effect is good, but it is very unfavorable in the long term. By blindly applying pesticides in excessive doses you are killing pests' natural enemies. If they are killed, the ecological balance of the farmland will be disrupted, and the resistance of the next generation of pests and diseases will be improved. This will require more pesticide, heavier pesticide, and it will fall into a vicious cycle. In the end ordinary people are the ones who suffer (Sun 2017: 174).

The expansion of scale farming in Ruilin has correlated with exponential increases in the use of petrochemicals and mechanized inputs. Between 2011 and 2013 the number of Ruilin dahu increased from 26 to 60 , while their production area grew by over $80 \%$ from $13,616 \mathrm{mu}$ (908 ha) to $24,558 \mathrm{mu}$ (1637 ha). During that time, annual pesticide use among Ruilin farmers increased from 19 to 52 tons, while chemical fertilizer use increased from 3255 tons to 4482 tons. Between 2007 and 2013 the number of medium and large-sized tractors in the township increased from 4 to 201, while the number of threshers increased from 111 to 197.

These policies and their outcomes have effectively transferred land to elites and non-Ruilin residents. In 2014 the township reduced the maximum contractable dahu landholding to $600 \mathrm{mu}$. But that year it also increased the security deposit to 600 yuan $/ m u$. As a result, prospective dahu still require at least 100,000 yuan (US $\$ 15,000$ ) in initial capital, an amount well outside the reach of most Ruilin small-scale farmers. By 2014, the township had transferred $53 \%$ of its arable land to $65 \mathrm{dahu}$, but $80 \%$ of the total consolidated land. Former Ruilin small- and mid-scale farmers represented 11 of 65 dahu, but they held only $7.3 \%$ of transferred township land. Dahu from outside of Ruilin held around 5\%. Of the remainder, $46 \%$ went to those who earned their start-up capital working in industries outside Ruilin, 26\% to those in townshipbased non-farm industries, $6.7 \%$ to village cadres, and $8.5 \%$ to wealthy villagers (Sun 2017). In addition, while by 2014 hukou-defined residents of Ruilin represented 40 of the 65 official dahu, 40 households were subcontracting at least $100 \mathrm{mu}$ (6.6 ha). Of these unofficial dahu, all were hukoudefined outsiders. As a former middle farmer told me:

No one who was a middle farmer in the past has become a dahu. If you want to contract land, you need social connections. We [small-scale farmers] don't have a social network, so the government won't let us contract land. You might want to contract but you can't. If I could contract land, I wouldn't go out to do manual labor.

Within only seven years, Ruilin was fundamentally altered. While 6873 residents were working as migrant laborers in 2007, that number more than doubled to 15,450 by 2012 . 
By 2014, the pre-reform number of middle farmers had decreased by $80 \%$. Along with the emptying out of villages and the loss of middle farmers, customs have also waned. Where every village organized a land festival [tudihui] up until the late 2000 s, by 2018 only the largest three of Ruilin's villages continued the tradition. As evidenced in Tai Village (Fig. 1), land consolidation has reduced vertical and horizontal landscape diversity. In the 2007-2008 phase of land consolidation alone over 320 irrigation ponds were eliminated.

The drastic reduction of the budget of Ruilin's agricultural extension station, its new focus on large-scale farmers, and its subsequent neglect of small-scale farmers has other widerreaching implications. The station's key duties include gathering annual data on the condition of the township's agricultural production and reporting it to the Ministry of Agriculture (MOA) where it is used to formulate agricultural policies. Yet the township station head acknowledged that his office ceased the practice of surveying small-scale households in the early 2010 s, and subsequently created statistics based on annual projections from previous years.

\section{Conclusion}

Ruilin on the eve of state-directed agricultural modernization was, like Ruilin during the Imperial era, hardly idyllic. In resilience terms, the system possessed many features and hallmarks that rendered it vulnerable to disturbances. Most notably, Ruilin farmers used most of their land to grow two seasons of rice, relying on industrially produced inputs and the state for a market, all of which undermined their autonomy and diversity. While the Ruilin government devoted resources to assisting small-scale farmers, it, like many rural governments at the time, also increasingly exploited them, funding its operations as it did via imposing often excessive taxes and fees. As I intend to show in future work, considerable inter-village power imbalances existed that supported the sustainability of some villages at the expense of others.

However, certain practices and features consistent with adaptive resilience remained at the time (Table 2). Ruilin's governance autonomy was bolstered by the presence of "middle farmers" active in grassroots governance and customs; diverse subsistence farming; and (to a certain extent) the role of small-scale farmers in providing revenue for the township government, which incentivized it to invest in extension and outreach. Small- and mid-scale subsistence farming helped to make the Ruilin system diverse in terms of land cover and land use, as well as in stakeholders. Ruilin built socioecological capital through its household-based farming system, the presence of grassroots leaders, and state-supported agricultural extension and research.

My fieldwork indicates that agricultural modernization reform has brought about the decline of these adaptive resilient features. Agricultural modernization devastated Ruilin's middle farmer population, directed the priorities of the diminished township government away from the majority of those they govern, and ushered in a production system premised on large-scale and industrialized monocropping. All these changes have reduced governance and ecological diversity, autonomy, and the system's ability to retain knowledge and organic soil matter. The shortterm consequences of this policy are already evident in increased vulnerability to disasters and land waste, reducing per-hectare productivity.

These changes do not necessarily portend imminent disaster. As Gunderson and Holling (2002) note, maladaptive systems can also achieve high levels of resilience. Ruilin, like its higher-level governing systems, may be able to

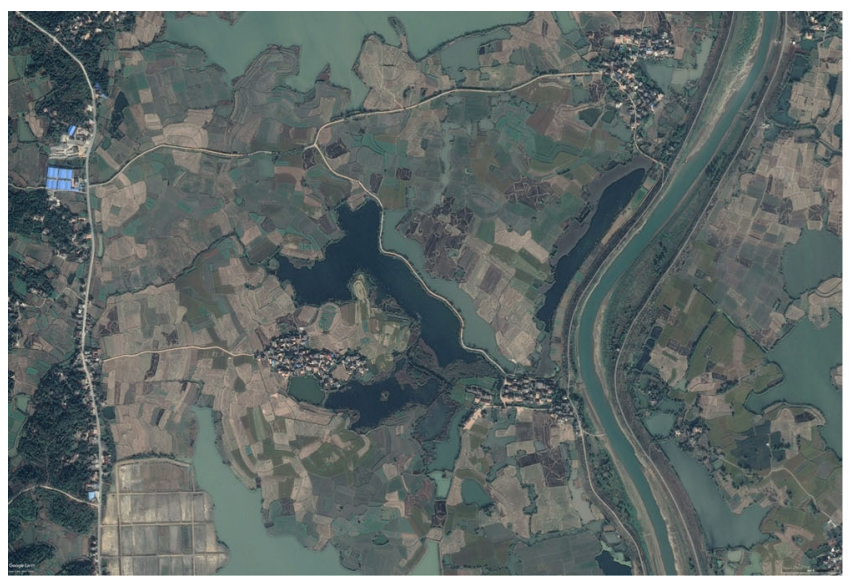

2013

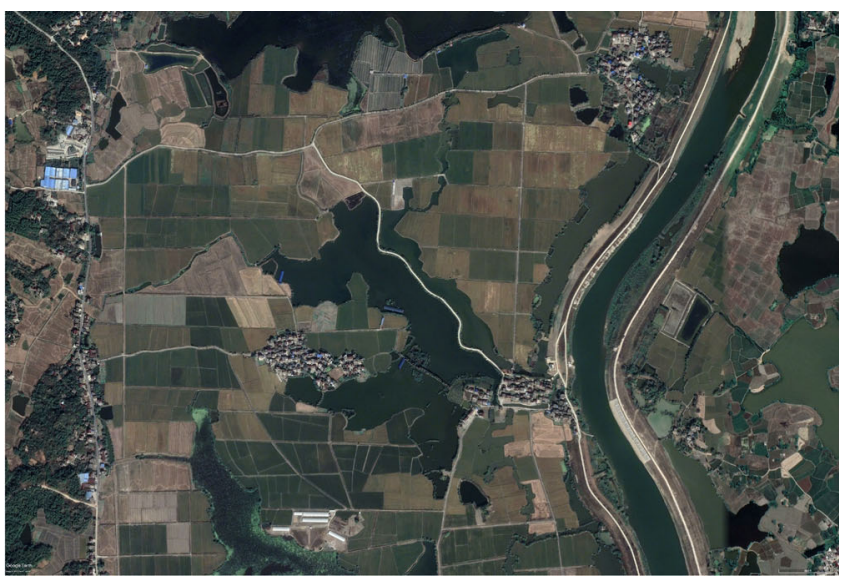

2015

Fig. 1 Tai Village, Ruilin Township, before and after land consolidation, 2013-2015 (Map data: Google, CNES/Airbus) 


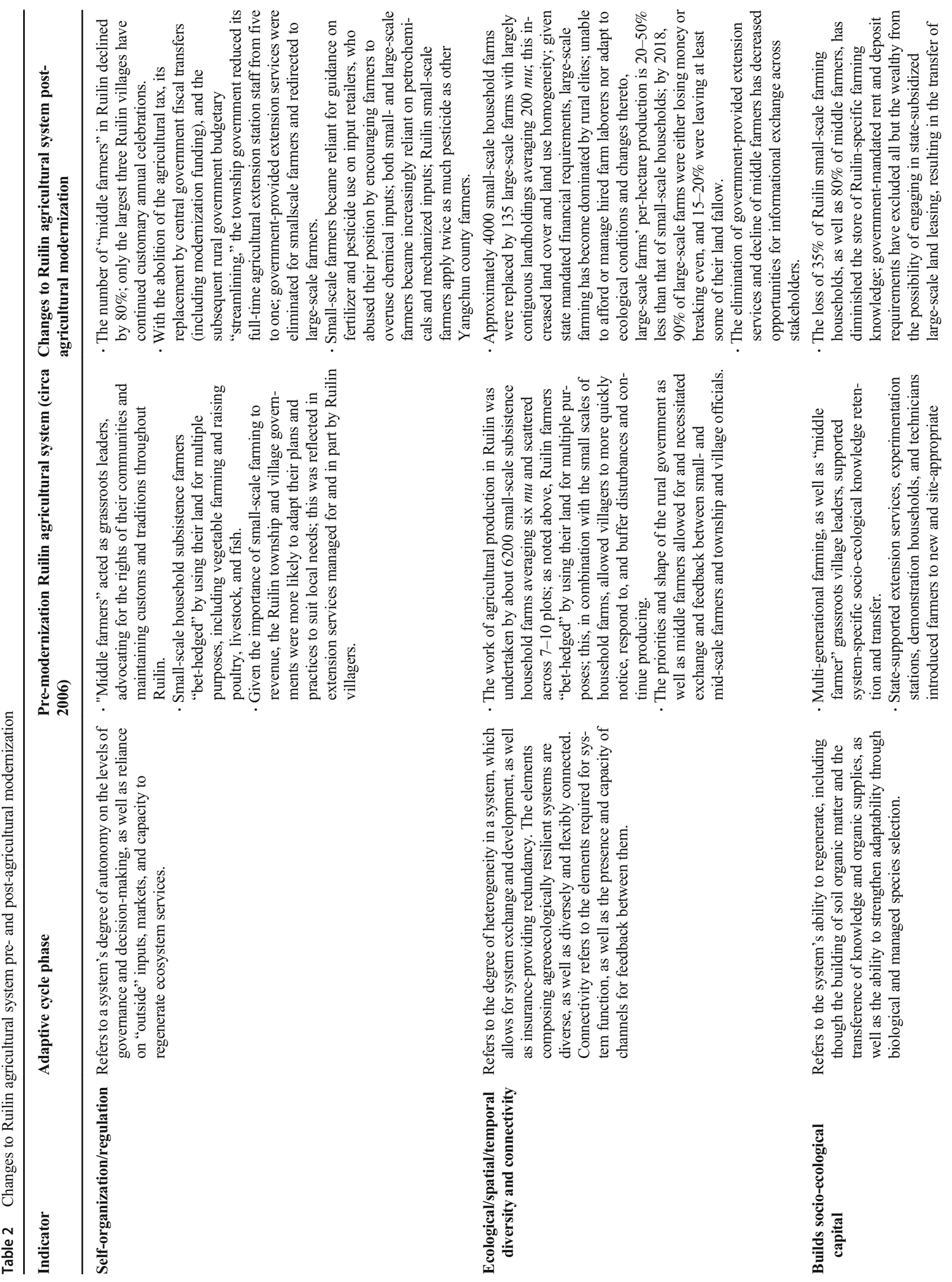




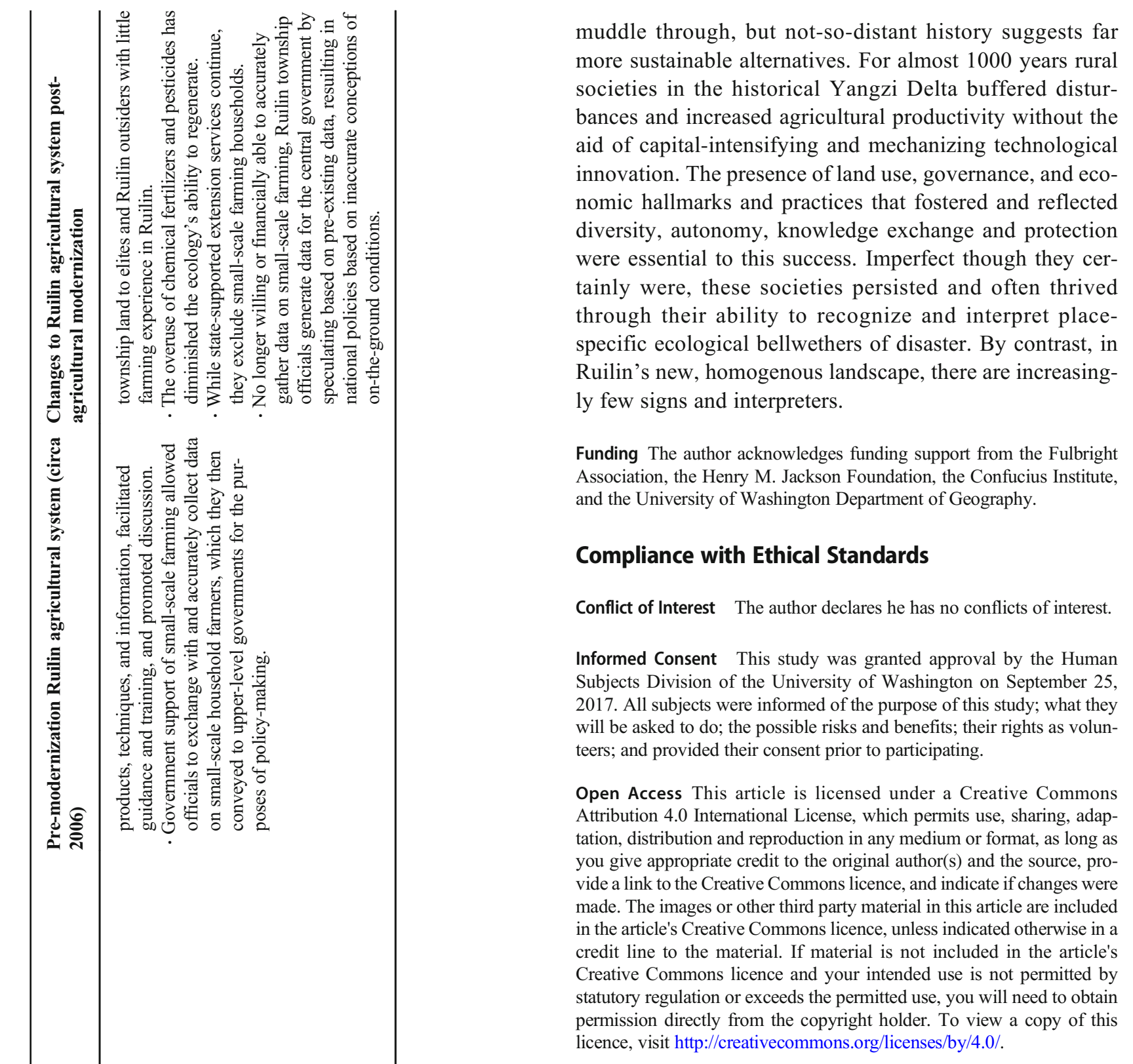

muddle through, but not-so-distant history suggests far more sustainable alternatives. For almost 1000 years rural societies in the historical Yangzi Delta buffered disturbances and increased agricultural productivity without the aid of capital-intensifying and mechanizing technological innovation. The presence of land use, governance, and economic hallmarks and practices that fostered and reflected diversity, autonomy, knowledge exchange and protection were essential to this success. Imperfect though they certainly were, these societies persisted and often thrived through their ability to recognize and interpret placespecific ecological bellwethers of disaster. By contrast, in Ruilin's new, homogenous landscape, there are increasingly few signs and interpreters.

Funding The author acknowledges funding support from the Fulbright Association, the Henry M. Jackson Foundation, the Confucius Institute,

Conflict of Interest The author declares he has no conflicts of interest.

Informed Consent This study was granted approval by the Human Subjects Division of the University of Washington on September 25, 2017. All subjects were informed of the purpose of this study; what they will be asked to do; the possible risks and benefits; their rights as volun; and provided their consent prior to participating.

Open Access This article is licensed under a Creative Commons Attribution 4.0 International License, which permits use, sharing, adapmade. The images or other third party material in this article are included in the article's Creative Commons licence, unless indicated otherwise in a statutory regulation or exceeds the permitted use, you will need to obtain licence, visit http://creativecommons.org/licenses/by/4.0/.

\section{References}

Becker, Jasper. 1996. Hungry Ghosts: China's Secret Famine. New York: Henry Holt.

Tengö, Maria and Kristina Belfrage. 2004. "Local Management Practices for Dealing with Change and Uncertainty: A Cross-Scale Comparison of Cases in Sweden and Tanzania." Ecology and Society 9 (3).

Berkes, Fikret, Johan Colding, and Carl Folke. 2000. "Rediscovery of Traditional Ecological Knowledge as Adaptive Management." Ecological Applications 10 (5). Ecological Society of America: 1251-62.

Bernhardt, Kathryn. 1992. Rent, Taxes, and Peasant Resistance: The Lower Yangzi Region, 1840-1950. Stanford: Stanford University Press. 
Bray, Francesca. 1986. The Rice Economies: Technology \& Development in Asian Societies. New York: Basil Blackwell.

Cabell, Joshua, and Myles Oelofse. 2012. "An Indicator Framework for Assessing Agroecosystem Resilience." Ecology and Society 17 (1).

Chan, Kam Wing. 2010. "Fundamentals of China's Urbanization and policy." China Review 10 (1): 63-93.

Chan, Kam Wing, and Yanning Wei. 2019. "Two Systems in One Country: The Origin, Functions, and Mechanisms of the RuralUrban Dual System in China." Eurasian Geography and Economics 60 (4): 422-454.

China Daily website. 2012. "China raises rice purchase prices." September 5. . http://www.chinadaily.com.cn/business/2012-09/ 05/content 15734401.htm.

China Daily website. 2013. "China Gives Agricultural Modernization 500m." August 18. . http://www.chinadaily.com.cn/china/2013-08/ 18/content_16901983.htm.

China Daily website. 2016. China to Invest $\$ 450$ b Modernizing Agriculture by 2020. September 19. . https://www.chinadaily.com. cn/business/2016-09/19/content_26828613.htm.

China Daily website. 2017. "China sets minimum prices for protective rice purchases." February 18. . https://www.chinadaily.com.cn/ china/2017-02/18/content_28251774.htm.

Cumming, Graeme, Cumming, David, and Redman, Charles. 2006. "Scale Mismatches in Social-Ecological Systems: Causes, Consequences, and Solutions." Ecology and Society 11 (1).

Day, Alexander F, and Mindi Schneider. 2018. "The End of Alternatives? Capitalist Transformation, Rural Activism and the Politics of Possibility in China†.” The Journal of Peasant Studies 45 (7): 1221-46.

Davis, Mike. 2000. "The Origin of the Third World." Antipode 32 (1). Dikötter, Frank. 2010. Mao's Great Famine. New York: Walker \& Co.

Eastman, Lloyd E. 1988. Family, Fields, and Ancestors: Constancy and Change in China's Social and Economic History, 1550-1949. New York: Oxford University Press.

Ellis, E. C., and S. M. Wang. 1997. "Sustainable Traditional Agriculture in the Tai Lake Region of China." Agriculture, Ecosystem and Environment 61: 177-193.

Elvin, M. 2004. The Retreat of Elephants: An Environmental History of China. New Haven: Yale University Press.

Fock, Achim, and Christine Wong. 2008. Financing Rural Development for a Harmonious Society in China: Recent Reforms in Public Finance and Their Prospects. Washington, D.C.: World Bank.

Garnaut, Anthony. 2014. "The Geography of the Great Leap Famine." Modern China 40 (3): 315-48.

Gotts, Nicholas. 2007. "Resilience, Panarchy, and World-Systems Analysis." Ecology and Society 12 (1).

Gunderson, Lance H., and Holling, C. S. 2002. Panarchy: Understanding Transformations in Human and Natural Systems. Washington, DC: Island Press.

Gürel, Burak. 2014. "Changing Relations of Production in Chinese Agriculture from Decollectivization to Capitalism." McGill Sociological Review 4: 67-92.

Hanstad, Tim, Robert Mitchell, and Roy L. Prosterman. 2009. One Billion Rising. Law, Land and the Alleviation of Global Poverty. Leiden: Leiden University Press.

He, Wenkai. 2015. "Public Interest and the Financing of Local Water Control in Qing China, 1750-1850." Social Science History 39 (3): 409-430.

He, Xuefeng. 2011. 取消农业税后农村的阶层及其分析 [An analysis of rural stratification post-agricultural tax abolition]. Culture and History Vision (Theory), April: 41-47.

Holling, C. S. 2001. "Understanding the complexity of economic, ecological, and social systems." Ecosystems 4: 390-405.

Huang, Philip C.C. 1990. The Peasant Economy and Rural Development in the Yangzi Delta, 1350-1988. Stanford, CA: Stanford University Press.
Jiang, Hong. 2003. "Stories Remote Sensing Images Can Tell: Integrating Remote Sensing Analysis with Ethnographic Research in the Study of Cultural Landscapes." Human Ecology 31 (2).

Kremen, Claire, Alastair Iles, and Christopher Bacon. 2012. "Diversified Farming Systems An Agroecological, Systems-Based Alternative to Modern Industrial Agriculture.” Ecology and Society 17 (4).

Kung, James Kai-sing Kang, Chenggang Xu, and Feizhou Zhou. 2013. "From Industrialization to Urbanization: The Social Consequences of Changing Fiscal Incentives on Local Governments' Behavior.' In Law and Economics with Chinese Characteristics: Institutions for Promoting Development in the Twenty-First Century, edited by David Kennedy and Joseph E. Stiglitz, 491-509. Oxford: Oxford University Press.

Li, Lillian. 1982. Introduction: Food, famine, and the Chinese state. Journal of Asian Studies XLI (4): 687-707.

Li, Z, Yang, Peilin, Yang, Li, and Peilin, Li. 2017. Reform and Development of Agriculture in China. Singapore: Springer Singapore.

Muldavin, Joshua. 2000. "The Paradoxes of Environmental Policy and Resource Management in Reform-Era China." Economic Geography 76 (3): 244-271.

The National People's Congress of the People's Republic of China. 1999. 宪法 (Constitution of the People's Republic of China). 4th ed. Beijing: Foreign Languages Press.

The National People's Congress of the People's Republic of China. 2002. Law of the People's Republic of China on Land Contract in Rural Areas. China.org.cn website. . http://www.china.org.cn/china/ LegislationsForm2001-2010/2011-02/12/content 21907969.htm.

O'Brien, Kevin J., and Lianjiang Li. 2006. Rightful Resistance in Rural China. Cambridge: Cambridge University Press.

Patton, Dominique. 2015. "China Farm Pollution Worsens, Despite Move to Curb Excessive Fertilizers, Pesticides." Reuters. April 14. . https://www.reuters.com/article/china-agriculture-pollution/chinafarm-pollution-worsens-despite-moves-to-curb-excessivefertilisers-pesticides-idUSL4N0XA3CO20150414.

Platt, Stephen R. 2012. Autumn in the Heavenly Kingdom: China, the West, and the Epic Story of the Taiping Civil War. New York: Alfred A. Knopf.

Schneider, Mindi. 2017. "Dragon Head Enterprises and the State of Agribusiness in China." Journal of Agrarian Change 17 (1): 3-21.

Sen, Amartya. 1989. "Food and Freedom." World Development 17 (6): $769-781$.

Shih, James C. 1992. Chinese Rural Society in Transition: A Case Study of the Lake Tai Area, 1368-1800. Berkeley: University of California Press.

Skinner William G. 1995. Marketing and Social Structure in Rural China. Ann Arbor: Association for Asian Studies.

Smil, Vaclav. 1999. "China's Great Famine: 40 Years Later." British Medical Journal 319: 1619-21.

Stavis, Benedict. 1974. Making Green Revolution: The Politics of Agricultural Development in China. Ithaca: Rural Development Committee, Cornell University.

Sun, Xinhua. 2017. 再造农业:皖南河镇的政府干预与农业转型(2007-2014) [Remaking Agriculture: Government Intervention and Agrarian Transition in River Township, Southern Anhui Province (20072014)]. Beijing: Social Sciences Academic Press (China).

Thomas, S.B. 1956. "Communist China's Agrarian Policy, 1954-56." Pacific Affairs 29 (2): 141-160.

Tian, Baihui. 2015. 明清徽州水旱灾害与民间应对 [“Flood and Drought Disasters in Huizhou in Ming and Qing Dynasties and Civilian Responses"]. Journal of Changzhou University (Social Science Edition) 16 (2): 75-80.

Tong, Chengli, Charles A.S Hall, and Hongqing Wang. 2003. "Land Use Change in Rice, Wheat and Maize Production in China (19611998)." Agriculture, Ecosystems and Environment 95 (2). 
Tsui, K. 2011. "China's Infrastructure Investment Boom and Local Debt Crisis." Eurasian Geography and Economics 52 (5): 686-711.

Tsui, K., and Y. Wang. 2004. "Between Separate Stoves and a Single Menu: Fiscal Decentralization in China." China Quarterly 177: 71-90.

Van Apeldoorn, Dirk, Kasper Kok, Marthijn Sonneveld, and Tom A. Veldkamp. 2011. "Panarchy Rules: Rethinking Resilience of Agroecosystems, Evidence from Dutch Dairy-Farming." Ecology and Society 16 (1).

Wang, Xiaobing, Futoshi Yamauchi, Keijiro Otsuka, and Jikun Huang. 2016. "Wage Growth, Landholding, and Mechanization in Chinese Agriculture." World Development 86.

Wen, Jiabao. 2006. "Report on the Work of the Government Delivered at the Fourth Session of the Tenth National People's Congress." March 5. China Report 42: 3.

Whiting Susan H. 2001. Power and Wealth in Rural China: The Political Economy of Institutional Change. New York: Cambridge University Press.

Whiting Susan H., Daniel Abramson, Shang Yuan, and Stevan Harrell. 2019. "A Long View of Resilience in the Chengdu Plain, China." Journal of Asian Studies 78 (2): 257-284.

Will, Pierre-Etienne, Roy Bin Wong, and James Z. Lee. 1991. Nourish the People: The State Civilian Granary System in China 1650-1850. Ann Arbor: Center for Chinese Studies, University of Michigan.
Yan, Hairong. 2008. New Masters, New Servants: Migration, Development, and Women Workers in China. Durham: Duke University Press.

Yang, Jisheng. 2007. 墓碑:中国六十年代大饥荒纪实 (Tombstone: A Factual Record of China's Great Famine of the 60s). Hong Kong: Cosmos.

Yangchun County Local Record Compiling Committee. 2003. Yangchun County Annals.

Ye, Jingzhong. 2015. "Land Transfer and the Pursuit of Agricultural Modernization in China." Journal of Agrarian Change 15 (3): 314-37.

Yun, Ying. 2006. "Research on Grassroots Agricultural Technology Extension System in China: A Historical and Theoretical Review". PhD Dissertation.

Zhang, Letian. 2005. Farewell to Ideals: A Study of the People's Commune System. Shanghai: Shanghai People's Publishing House.

Zhang, Qian Forrest, and John A. Donaldson. 2008. "The Rise of Agrarian Capitalism with Chinese Characteristics: Agricultural Modernization, Agribusiness and Collective Land Rights." The China Journal 60 (60).

Zhao, Shukai. 2007. "The Power System of Township Governments." Chinese Sociology \& Anthropology 39 (2): 8-16.

Publisher's Note Springer Nature remains neutral with regard to jurisdictional claims in published maps and institutional affiliations. 